\title{
PRESENCE OF DOMESTICATED CATS AND VISUAL IMPAIRMENT ASSOCIATED TO Toxoplasma gondii SERUM POSITIVE CHILDREN AT AN ELEMENTARY SCHOOL IN JATAIZINHO, STATE OF PARANÁ, BRAZIL
}

\author{
FABIANA MARIA R. LOPES ${ }^{1}$; DANIELA DIB GONÇALVES' ${ }^{1}$; CÉLIA R. DOS REIS ${ }^{1}$; REGINA M. BREGANÓ2; \\ ROBERTA L. FREIRE ${ }^{3}$; JULIO CÉSAR DE FREITAS ${ }^{3}$; ITALMAR T. NAVARRO ${ }^{3 *}$
}

\begin{abstract}
LOPES, F.M.R.; GONÇALVES, D.D.; REIS, C.R. DOS; BREGANÓ, R.M.; FREIRE, R.L.; FREITAS, J.C. DE; NAVARRO, I.T. Presence of domesticated cats and visual impairment associated to Toxoplasma gondii serum positive children at an elementary school in Jataizinho, state of Paraná, Brazil. [Presença de gatos domésticos e alterações visuais associados a amostras positivas para Toxoplasma gondii em escolares de Jataizinho, Paraná, Brasil]. Revista Brasileira de Parasitologia Veterinária, v. 17, n. 1, p.12-15. 2008. Departamento de Medicina Veterinária Preventiva, Centro de Ciências Agrárias, UEL, Caixa Postal 6001, Londrina, PR 86051-990, Brasil. E-mail: italmar@uel.br

Toxoplasmosis possess worldwide geographic distribution and high serological prevalence in human beings and animals. Acquired way is, in the majority of the times, light or asymptomatic however, in approximately $15 \%$ of the cases can be developed the ocular form. The aim of this study is to research the occurrence of IgG antiToxoplasma gondii antibodies in children at an elementary school in Jataizinho (PR) and relate some factors with the epidemiology of the toxoplasmosis. A total of 276 samples of blood by using indirect immunofluorescence (IFA) where 128 (46.4\%) were detected positives. The analysis of the variables indicated that the presence of domestic cats in the household was an important factor associated to the infection by $T$. gondii $(\mathrm{OR}=3.45 ; 1.61$ 7.45) as well as to the children who described any kind of visual impairment (OR=3.19; 1.11 - 9.35).
\end{abstract}

KEY WORDS: Toxoplasmosis, schoolchildren, epidemiology, risk factor, cats.

\section{RESUMO}

A toxoplasmose possui ampla distribuição geográfica e elevada prevalência sorológica entre seres humanos e animais. A forma adquirida é, na maioria dos casos, leve ou assintomática, entretanto, em aproximadamente $15 \%$ dos casos pode-se desenvolver a forma ocular. O objetivo deste trabalho foi relacionar algumas variáveis à ocorrência de anticorpos IgG antiToxoplasma gondii em escolares do ensino fundamental de Jataizinho (PR). Foram analisadas amostras de sangue de 276 crianças testadas pela reação de imunofluorescência indireta (IFI) onde 128 (46,4\%) foram positivas. A análise das variá-

\footnotetext{
${ }^{1}$ Programa de Pós-Graduação em Ciência Animal, Departamento de Medicina Veterinária Preventiva, Universidade Estadual de Londrina (UEL), Londrina, PR 86051-990, Brasil.

${ }^{2}$ Departamento de Ciências Patológicas, UEL, Londrina, PR 86051990.

${ }^{3}$ Departamento de Medicina Veterinária Preventiva, Centro de Ciências Agrárias, UEL, Caixa Postal 6001, Londrina, PR 86051-990, Brasil. Email: italmar@uel.br
}

veis revelou que a presença de gato doméstico foi um importante fator associado à infecção pelo $T$. gondii $(\mathrm{OR}=3.45$; 1.61- 7.45) assim como crianças que relataram algum tipo de alteração visual $(\mathrm{OR}=3.19 ; 1.11$ - 9.35).

PALAVRAS-CHAVE: Toxoplasmose, escolares, epidemiologia, fatores de risco, gatos.

\section{INTRODUCTION}

Toxoplasmosis is a worldwide spread infection caused by Toxoplasma gondii protozoan, being the human being, other mammals and birds its intermediary hosts (LOPES et al., 2005). The infection in humans can occur by the ingestion of sporulated oocysts in contaminated water and food, by the ingestion of bradyzoites in raw or badly-cooked meat, by transplacental transmission by tachyzoites (ABREU et al., 2001). Also by blood transfusion and organ transplant, being the least important (HILL; DUBEY, 2002).

Toxoplasmosis can develop into a severe systemic illness when in its congenital form, in which the mother, when infected 
for the first time during pregnancy, can present a temporary parasitemy with focal lesions generated within the placenta, thereby infecting the fetus (DUBEY, 1977). Although congenital toxoplasmosis may be asymptomatic at birth, ocular problems may manifest later in life (MONTOYA; LIESENFELD, 2004).

According to Meenken et al. (1995), approximately 80\% of children diagnosed with sub-clinical toxoplasmic infection present ocular sequels at some point in their lives. Lesions to the retina are the most frequent sequels, and they can be easily detected in ophthalmological examinations. These signs indicate that the neurological symptoms are possibly involved.

Information about congenital transmission of toxoplasmosis during pregnancy, post-birth or even in first childhood are fundamental for a ready intervention and for soothing the possible consequences of this infection.

In Córdoba, Argentina, a study determinate the seroprevalence of toxoplasmosis in infant and young children population ( 0 to 15 years) and the authors found $51.75 \%$ of positivity (CHIARETTA et al., 2003). The prevalence status of T. gondii infection in children of the Democratic Republic of Sao Tome and Principe, Western Africa was 21.49\% (FAN et al., 2006).

In Rolândia, Paraná (PR) prevalence of $42 \%$ of positive serum for $T$. gondii was found at the urban zone while $43 \%$ at the rural one in schoolchildren in their first to fourth year of schooling (GIRALDI et al., 2001) when in Jaguapitã (PR), a prevalence of $44 \%$ was found in children and teenagers aged up to 15 years old (GARCIA et al., 1999). In students at High School in São Jerônimo da Serra (PR) the prevalence of positive serum for T. gondii was 50.4\% (LOPES et al., 2005).

Due to gravity of the injuries caused for the $T$. gondii, the precocious diagnosis is important to apply the adequate intervention, mainly in the cases where the clinical symptoms and the serology results are not conclusive (NUSSENBLATT; BELFORT, 1994).

The aim of this study is to determinate the occurrence of IgG anti-T. gondii antibodies in children at an elementary school from the municipal system in Jataizinho (PR) and relate the associated factors with toxoplasmosis.

\section{MATERIAL AND METHODS}

Population studied: 276 blood samples were voluntarily collected from children between 4 and 11 years old at an elementary school in the municipal system of Jataizinho, Paraná, Brazil. Considering that the city possess, approximately, 2300 students on elementary school in the municipal system (IPARDES, 2007), to determinate the sample size was estimate a prevalence of $45 \%$, with precision of $6 \%$ and $5 \%$ of significancy level.

Material collection: The blood samples were collected by a professional nurse of Posto de Saúde Central from Jataizinho, using vacutainer ${ }^{\circledR}$ system, by venous puncture in each child. The material was kept at room temperature until coagula retraction. Serum was stored in sterile containers and kept at $-20^{\circ} \mathrm{C}$ until its use.
Epidemiological Questionnaire: Factors associated with toxoplasmosis in the group studied were determined through the use of an epidemiological questionnaire to the parents of the children. The following variables were analyzed: gender, age group, schooling, contact with animals, presence of cats, whether the animal has access to vegetable gardens, habit of playing in sand, ingestion of raw/badly cooked meat, habit of washing food, presence of any eye problems.

Exams performed: For antibody anti-T. gondii research, sera samples were submitted to indirect immunofluorescence assay (IFA) (CAMARGO, 1964) being considered positive titers e" 16 and the reactions were observed in Epifluorescence microscope (LEICA), with increase of 400X.

Statistical analysis: The results obtained after the study of the variables were submitted to statistical analysis by chisquare test $\left(\chi^{2}\right)$ corrected by Yates or Fisher Test, using Epi6 version 6.04 statistic program, adopting 95\% confiance interval (CI) (DEAN et al., 1994).

Ethics Committee: The research was approved by the Ethics in Research Committee of the Hospital Universitário Regional do Norte do Paraná - Decision CEP 142/03.

\section{RESULTS AND DISCUSSION}

From the analyzed samples, 128 were positive (46.4\%). Titers greater than 1024 accounted for $53.10 \%$, the highest being of 16,384 found in three analyzed samples (2.35\%) (Figure 1). Similar results were found in the city of Rolândia (PR) (45.4\% - schoolchildren aged above tem years old in the urban zone) (GIRALDI et al., 2002) and in the city of Jaguapitã (PR) (44\% - children aged 15 years old or younger) (GARCIA et al., 1999). A study released in Fortaleza (CE) showed that the seroprevalence according to age ranges was $40.0 \%$ (2 to 9 years) and $60.4 \%$ (10-19 years). T. gondii seroprevalence increased rapidly with age, suggesting that most of the primary infection is acquired during childhood (REY; RAMALHO, 1999).

The high titers found for toxoplasmosis (higher than 1024 $-53.10 \%$ ) suggest recent infection. These cases, specifically, need further studies including clinical analysis, seen that these children can present the sub clinical form of the infection and suffer later consequences.

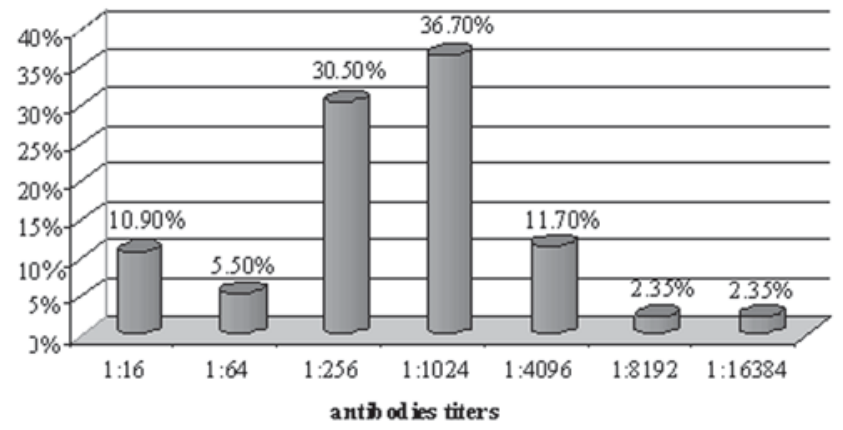

Figure 1. Distribution of serological titers of IgG anti-Toxoplasma gondii antibodies detected through IFA in schoolchildren at elementary school in the municipal system of Jataizinho, PR, 2004. 
Table 1. Results from Chi-square test $\left(\chi^{2}\right)$ in relation to variables analysed to determine the associated factors for toxoplasmosis in schoolchildren at elementary school in the municipal system of Jataizinho, PR, 2004.

\begin{tabular}{|c|c|c|c|c|c|c|}
\hline \multirow{2}{*}{$\frac{\text { Variables }}{\text { Presence of domestic cat }}$} & \multicolumn{2}{|c|}{ Reagents (\%) } & \multirow{2}{*}{$\begin{array}{c}\text { No reagents }(\%) \\
18(39.1)\end{array}$} & \multirow{2}{*}{$\frac{p}{0.0008}$} & \multirow{2}{*}{$\frac{\chi^{2}}{11.11}$} & \multirow{2}{*}{$\frac{\mathrm{OR}(\mathrm{Cl} 95 \%)}{3.45(1.61-7.45)}$} \\
\hline & yes & $28(60.9)$ & & & & \\
\hline & no & $37(31.1)$ & $82(68.9)$ & & & \\
\hline \multirow[t]{2}{*}{ Report any kind of visual impairment } & yes & $14(63.9)$ & $8(36.4)$ & 0.0285 & 4.79 & $3.19(1.11-9.35)$ \\
\hline & no & $34(35.4)$ & $62(64.6)$ & & & \\
\hline \multirow[t]{2}{*}{ Vegetable gardens with protection } & yes & $5(20.0)$ & $20(80.0)$ & 0.0218 & 5.25 & $0.19(0.04-0.82)$ \\
\hline & no & $12(57.1)$ & 9 (42.9) & & & \\
\hline \multirow[t]{2}{*}{ Age group } & $0-6$ years & $13(24.0)$ & $41(76.0)$ & 0.0094 & 6.73 & $0.37(0.17-0.80)$ \\
\hline & $>6$ years & $52(46.4)$ & $60(53.6)$ & & & \\
\hline \multirow[t]{2}{*}{ Residence } & rural zone & $0(0.0)$ & $2(100.0)$ & 0.6819 & 0.16 & - * \\
\hline & urbana zone & $57(39.6)$ & $87(60.4)$ & & & \\
\hline \multirow[t]{2}{*}{ Consumption water public } & system & 65 (39.9) & $98(60.1)$ & 0.4206 & 0.64 & $-*$ \\
\hline & well & $0(0.0)$ & $3(100.0)$ & & & \\
\hline \multirow[t]{2}{*}{ Consumption vegetables raw } & yes & $57(38.5)$ & $91(61.5)$ & 0.8172 & 0.05 & $1.27(0.47-3.42)$ \\
\hline & no & $8(44.4)$ & $10(55.6)$ & & & \\
\hline \multirow[t]{2}{*}{ Ingestion of raw meat/badly cook } & yes & $2(40.0)$ & $3(60.0)$ & 0.6598 & 0.19 & $1.02(0.16-6.32)$ \\
\hline & no & $56(39.4)$ & $86(60.3)$ & & & \\
\hline \multirow[t]{2}{*}{ Presence of vegetables gardens } & yes & $17(37.0)$ & $29(63.0)$ & 0.8514 & 0.03 & $1.13(0.56-2.30)$ \\
\hline & no & $46(40.0)$ & $69(60.0)$ & & & \\
\hline \multirow[t]{2}{*}{ Irrigation of vegetables gardens } & public system & $16(38.1)$ & $26(61.9)$ & 0.6851 & 0.16 & $1.62(0.09-27.83)$ \\
\hline & river/stream & $1(50.0)$ & $1(50.0)$ & & & \\
\hline
\end{tabular}

* Undefinited Odds Ratio

The analysis of the variables indicated that the presence of domestic cats in the household was an important factor associated to the infection by $T$. gondii $(\mathrm{OR}=3.45 ; 1.61-7.45)$ as well as to the children who described any kind of visual impairment (OR= 3.19; 1.11 - 9.35). Chiaretta et al. (2003) found that the coexistence with cats and/or dogs was defined as a risk factor to toxoplasmosis in infant and young children population (0 to 15 years) in Córdoba, Argentina. However, there were no statistically significant differences about residence, consumption water, consumption vegetables raw, ingestion of raw meat/badly cook, presence of vegetable gardens and irrigation of vegetable gardens.

The individuals who had a vegetable garden with any protection prohibiting the entrance of animals presented less chance of being infected $(\mathrm{OR}=0.19 ; 0.04-0.82)$ as well as the children between zero and six years old $(\mathrm{OR}=0.37$; 0.17 0.80).

All students whose sera presented positive results for toxoplasmosis should be submitted to ophthalmologic exams due to the potential risk of developing ocular toxoplasmosis. These cases can be a result of acquired or vertical transmission. Control and prevention measures should be adopted in the city in order to decrease transmission and avoid most severe cases, mainly congenital toxoplasmosis.

Acknowledgements:- The authors would like to thank the workers of the Posto de Saúde Central at the Municipality of
Jataizinho in the state of Paraná, for their attention and constant collaboration.

\section{REFERENCES}

ABREU, C.B.; NAVARRO, I.T.; BALARIN, M.R.S.; BRACARENSE, A.P.F.R.L.; MARANA, E.R.M.; TRAPP, S.M.; FUGINAKA, C.A.; PRUDÊNCIO, L.B.; MATOS, M.R.; TSUTSUI, V.S. Aspectos clínicos, patológicos e sorológicos da toxoplasmose experimental em cães jovens. Semina, v. 22, n. 2, p. 123-130, 2001.

CAMARGO, M.E. Improved technique of indirect immunofluorescence for serological diagnosis of toxoplasmosis. Revista do Instituto de Medicina Tropical, v. 6, n. 3, p. 117-118, 1964.

CHIARETTA, A.E.; SBAFFO, A.M.; CRISTOFOLINI, A.L.; MOLINA, M.D. Estudio seroepidemiológico de la toxoplasmosis en niños de áreas de riesgo de la ciudad de Río Cuarto, Córdoba, Argentina. Parasitología Latinoamericana, v. 58, n. 3-4, p. 112-117, 2003.

DEAN, A.G.; DEAN, J.A.; COULOMERIER, D.; BRENDEL, K.A.; SMITH, D.C.; BURTON, A.H.; DICKER, R.C.; SULIVAN, K.M.; FAGAN, R.F.; ARNER, T.G. Epi Info, Version 6: a word processing, data bases, and statistic program for epidemiology on microcomputers. Atlanta. Center for Diseases Control and Prevention, 1994.

DUBEY, J.P. Toxoplasma, Hammondia, Besnoitia, Sarcocystis 
and other tissue cyst-forming coccidia of man and animals. In: Kreier, J.P. Parasitic Protozoa. New York: Academic Press; v. 3, p. 101, 1977.

FAN, C.K.; HUNG, C.C.; SU, K.E.; SUNG, F.C.; CHIOU, H.Y.; GIL, V.; FERREIRA, M.C.R.; CARVALHO, J.M.; CRUZ, C.; LIN, Y.K.; TSENG, L.F.; SAO, K.Y.; CHANG, W.C.; LAN, H.S.; CHOU, S.H. Seroprevalence of Toxoplasma gondii infection among pre-schoolchildren aged 15 years in the Democratic Republic of Sao Tome and Principe, Western Africa. Transactions of the Royal Society of Tropical Medicine and Hygiene, v. 100, n. 5, p. 446449, 2006.

GARCIA, J.L.; NAVARRO, I.T.; OGAWA, L.; OLIVEIRA, R.C.; KOBILKA, E. Soroprevalência, epidemiologia e avaliação da toxoplasmose humana na zona rural de Jaguapitã (Paraná), Brasil. Revista Panamericana de Salud Pública, v. 6, n. 3, p. 157-163, 1999.

GIRALDI, N.; VIDOTTO, O.; NAVARRO, I.T.; GARCIA, J.L.; OGAWA, L.; KOBILKA, E. Toxoplasma antibody and stool parasite in public schoolchildren, Rolândia, Paraná, Brazil. Revista da Sociedade Brasileira de Medicina Tropical, v. 35, n. 3, p. 215-219, 2002.

HILL, D.; DUBEY, J.P. Toxoplasma gondii: transmission, diagnosis and prevention. Clinical Microbiology and Infection, v. 8, n.10, p. 634-640, 2002.
IPARDES: Instituto Paranaense de Desenvolvimento Econômico e Social. Disponível em: <http://www.ipardes.gov.br/ > Acesso em: 20 set. 2007.

LOPES, F.M.R.; MITSUKA BREGANÓ, R.; CONCHON COSTA, I.; CARLETTI, R. T.; REIS, C.R.; GONÇALVES, D.D.; NAVARRO, I.T.; FREIRE, R.L. Ocorrência de anticorpos IgG anti- Toxoplasma gondii em alunos do ensino médio do município de São Jerônimo da Serra - PR, Brasil. Revista Brasileira de Análises Clínicas, v. 37, n. 2, p. 109-111, 2005.

MEENKEN, C.; ASSIES, J.; VAN NIEUWENHUIZEN, O.; HOLWERDA-VAN DER MAAT, W.G.; VAN SCHOONEVELD, M.J.; DELLEMAN, W.J.; KINDS, G.; ROTHOVA, A. Long term ocular and neurological involvement in severe congenital toxoplasmosis. British Journal of Ophthalmology, v. 79, n. 6, p. 581-584, 1995.

MONTOYA, J.G.; LIESENFELD, O. Toxoplasmosis. Lancet, v. 363, n. 9425, p.1965- 1976, 2004.

NUSSENBLATT, R.B.; BELFORT JR, R. Ocular Toxoplasmosis: An old disease revisited. Journal of American Medical Association, v. 271, n. 4, p. 304-307, 1994.

REY, L.C.; RAMALHO, I.L.C. Seroprevalence of toxoplasmosis in Fortaleza, Ceará, Brazil. Revista do Instituto de Medicina Tropical de São Paulo, v. 41, n. 3, p. 171-174, 1999.

Received on July 21, 2006.

Accepted for publication on March 24, 2007. 